\title{
Association between human papillomavirus and Epstein - Barr virus DNA and gene promoter methylation of $R B 1$ and $C D H 1$ in the cervical lesions: a transversal study
}

Thaís M McCormick', Nathalie HS Canedo², Yara L Furtado ${ }^{3}$, Filomena A Silveira ${ }^{3}$, Roberto J de Lima ${ }^{3}$, Andréa DF Rosman ${ }^{3}$, Gutemberg L Almeida Filho ${ }^{3}$ and Maria da Glória da C Carvalho ${ }^{1,4^{*}}$

\begin{abstract}
Background: Human papillomavirus (HPV) inactivates the retinoblastoma 1 (RB1) gene by promoter methylation and reduces cellular E-cadherin expression by overexpression of DNA methyltransferase 1 (DNMT1). The Epstein-Barr virus (EBV) is an oncogenic virus that may be related to cervical carcinogenesis. In gastric cancer, it has been demonstrated that E-cadherin gene (CDH1) hypermethylation is associated with DNMT1 overexpression by EBV infection. Our aim was to analyze the gene promoter methylation frequency of $R B 1$ and $C D H 1$ and verify the association between that methylation frequency and HPV and EBV infection in cervical lesions.

Methods: Sixty-five samples were obtained from cervical specimens: 15 normal cervices, 17 low-grade squamous intraepithelial lesions (LSIL), 15 high-grade squamous intraepithelial lesions (HSIL), and 18 cervical cancers. HPV and EBV DNA testing was performed by PCR, and the methylation status was verified by MSP.

Results: HPV frequency was associated with cervical cancer cases $(p=0.005)$ but not EBV frequency $(p=0.732)$. Viral co-infection showed a statistically significant correlation with cancer $(p=0.027)$. No viral infection was detected in $33.3 \%(5 / 15)$ of controls. RB1 methylated status was associated with cancer $(p=0.009)$ and HPV infection $(p=0.042)$. CDH1 methylation was not associated with cancer $(p=0.181)$. Controls and LSIL samples did not show simultaneous methylation, while both genes were methylated in 27.8\% (5/18) of cancer samples. In the presence of EBV, CDH1 methylation was present in $27.8 \%$ (5/18) of cancer samples. Only cancer cases presented RB1 promoter methylation in the presence of HPV and EBV (33.3\%).

Conclusions: The methylation status of both genes increased with disease progression. With EBV, RB1 methylation was a tumor-associated event because only the cancer group presented methylated RB1 with HPV infection. HPV infection was shown to be significantly correlated with cancer conditions. The global methylation frequency was higher when HPV was present, showing its epigenetic role in cervical carcinogenesis. Nevertheless, EBV seems to be a cofactor and needs to be further investigated.
\end{abstract}

Virtual Slides: The virtual slide(s) for this article can be found here: http://www.diagnosticpathology.diagnomx.eu/vs/ 1159157579149317.

Keywords: Cervical cancer, HPV, EBV, Methylation, RB1,CDH1

\footnotetext{
*Correspondence: gloria@gcarvalho.org

'Laboratory of Molecular Pathology, Pathological Anatomy Service and

Pathology Department, Clementino Fraga Filho University Hospital, Federal

University of Rio de Janeiro - UFRJ, Rio de Janeiro, Brazil

${ }^{4}$ Serviço de Anatomia Patológica, Subsolo - sala 09 (Citopatologia), Hospital

Universitário Clementino Fraga Filho, UFRJ, Ilha do Fundão, Rio de Janeiro, RJ

CEP 21941-913, Brazil

Full list of author information is available at the end of the article
} 


\section{Background}

Cervical cancer represents an important public health problem, as it is the fourth most common type of carcinoma in women worldwide. This disease was responsible for 265,000 deaths in 2012, of which $87 \%$ occurred in developing countries [1]. According to the National Cancer Institute (INCA-Brazil), in general, its mortality/ incidence ratio is $52 \%$ [2] and its survival rate is $70 \%$ [1].

Genital human papillomavirus (HPV) infection causes virtually all cervical cancer cases [3], and the factors correlated with development from the initial lesion to invasive carcinoma are poorly understood [4]. The 40 genotypes of genital HPVs can be classified as low-risk and high-risk based on their oncogenic ability [5]. Among the high-risk HPVs (HR-HPV), HPV16 is of major clinical importance, causing over $50 \%$ of cervical cancer cases [6].

Cervical carcinogenesis is a stepwise process in which genetic and epigenetic abnormalities are seen in regulatory genes. Epigenetic alterations may modify the expression of HPV genes or even host genes, leading to silencing of tumor suppressor genes (TSGs) by promoter hypermethylation [7].

The E7 HPV oncoprotein is essential for the host cell transformation and immortalization process [8]. It is known that this oncoprotein inactivates the retinoblastoma 1 (RB1) gene by promoter methylation, which is essential in cervical tumorigenesis in humans [9]. E7 also has the ability to reduce cellular expression of E-cadherin, one of the major cell adhesion molecules, by overexpression of DNA methyltransferase 1 (DNMT1), an enzyme responsible for maintaining methylation patterns [10]. Thus, the cellular reduction of E-cadherin by gene promoter methylation may indicate a risk of local invasion and metastasis.

The Epstein-Barr virus (EBV), a member of the human herpes virus group, has been suggested as another oncogenic virus related to cervical carcinogenesis, as it is present in subclinical infection and invasive carcinoma of the cervix [11]. In gastric cancer, it has been demonstrated that hypermethylation of $C D H 1$, which expresses the E-cadherin protein, is associated with DNMT1 overexpression by EBV infection [12]. However, until now, this association with cervical carcinogenesis has not been described.

The relationship between viruses and cancer is well established. However, the epigenetic pathways that determine the regression or persistence of infection and also the progression from precursor lesions to cancer are not clear. Therefore, our aim was to analyze the gene promoter methylation frequency of $R B 1$ and $C D H 1$ and to verify the association between that methylation frequency and HPV and EBV infection in cervical lesions as well as in normal cervical epithelia.

\section{Methods}

Samples

This transversal study was performed with samples obtained from cervical specimens of 65 women over the age of 18 who attended the Cervical Pathology Outpatient Clinic of the Gynecology Institute of the Federal University of Rio de Janeiro, Brazil, between July 2006 and July 2013, excluding only unavailable samples and/ or those in poor condition. Because of those exclusion criteria, we worked with 65 samples.

The control samples were obtained from 15 cervical specimens with normal cytology and colposcopy, and 50 patients showing prior cytology with cervical lesions were classified by its cytological alterations as follows: 17 low-grade squamous intraepithelial lesions (LSILs), 15 high-grade squamous intraepithelial lesions (HSILs), and 18 cervical cancers.

Patients showing cytology with a diagnosis of HSIL or cancer were submitted to guided colposcopy biopsy, and cells were obtained from cervical brushings from patients with LSIL as well as from the control group.

The cervical smears and biopsies were taken as part of a routine screening program for cervical carcinoma. The cervical smears were collected with cervix brushes in phosphate-buffered saline, and the biopsies were obtained by cervical conization. All samples were analyzed in the Pathological Anatomy Laboratory from the same Gynecology Institute and were reviewed and classified by a certified pathologist.

This research was approved by ethical review boards from the Maternity School of the Federal University of Rio de Janeiro. Patients were asked to participate in the study, and informed consent was obtained before sample collection.

\section{DNA extraction}

The DNA extraction of the biopsy samples and cervical brushings was performed as described by Lattario et al. (2008) [13]. Briefly, these samples were digested in 500 $\mu \mathrm{L}$ of solution containing $10 \mathrm{mM}$ Tris- $\mathrm{HCl}, \mathrm{pH} 7.5,10$ $\mathrm{mM} \mathrm{NaCl}, 2 \%$ SDS, $10 \mathrm{mM}$ EDTA, pH 8.0, and $15 \mu \mathrm{L}$ $10 \mathrm{mg} / \mathrm{mL}$ proteinase $\mathrm{K}$ and incubated for 16 hours at $55^{\circ} \mathrm{C}$, followed by phenol-chloroform (1:1) extraction. The DNA was precipitated using ethanol at $-20^{\circ} \mathrm{C}$ for 16 hours, and then the samples were washed with $80 \%$ ethanol, re-suspended in $20 \mu \mathrm{L}$ of water and stored at $-20^{\circ} \mathrm{C}$ until use.

The DNA was isolated by previous PCR amplification with exon 5 p53 primers as an internal marker to ensure that the isolated DNA from samples and the following PCR were performed correctly, as described by Pestener et al. (1994) [14]. 


\section{Detection of HPV and EBV}

HPV and EBV DNA testing was performed using PCR methods. Detection of HPV was performed with the MY09 e MY11 [15] consensus primers, which amplify a 450-bp fragment. To detect EBV, we used consensus primers TC67 and TC69 [16], whose product is $288 \mathrm{bp}$. Both amplifications were performed in a thermocycler. The protocol for HPV detection was as follows: 5 minutes of initial denaturing at $95^{\circ} \mathrm{C} ; 35$ cycles at $95^{\circ} \mathrm{C}$, at $60^{\circ} \mathrm{C}$ and at $72^{\circ} \mathrm{C}$ for 1 minute at each temperature; and a final elongation step at $72^{\circ} \mathrm{C}$ for 10 minutes. The PCR for EBV detection was performed as follows: 1 minute of denaturing at $95^{\circ} \mathrm{C}$; followed by 40 cycles of 1 minute at $94^{\circ} \mathrm{C}, 2$ minutes at $55^{\circ} \mathrm{C}$ and 1 minute at $72^{\circ} \mathrm{C}$; and a final elongation of 5 minutes at $72^{\circ} \mathrm{C}$. The amplicons were stored at $4^{\circ} \mathrm{C}$ until time of use. HeLa and Raji cell lines were used as positive reaction controls for HPV and EBV, respectively. Samples containing just the reaction mixture without the template were analyzed as negative controls.

\section{Bisulfite treatment}

The extracted genomic DNA underwent sodium bisulfite modification as described by Rosas et al. (2001) [17]. This method transforms the unmethylated cytosines into uracils and does not alter the methylated cytosines. Briefly, $1 \mu \mathrm{g}$ of genomic DNA was diluted in $50 \mu \mathrm{L}$ of distilled water and denatured in $0.2 \mathrm{M} \mathrm{NaOH}$ for 10 $\min$ at $37^{\circ} \mathrm{C}$. The denatured DNA was then resuspended in $550 \mu \mathrm{L}$ of freshly prepared solution containing 10 $\mathrm{mM}$ hydroquinone (Sigma, St. Louis, $\mathrm{MO}$ ) and $3 \mathrm{M}$ sodium bisulfite, $\mathrm{pH} 5.0$ (Sigma), and incubated at $50^{\circ} \mathrm{C}$. After 16 hours of incubation, the DNA samples were desalinated through a column (Wizard DNA Clean-Up System, Promega, Madison, WI), treated with $0.3 \mathrm{M}$ $\mathrm{NaOH}$ for $15 \mathrm{~min}$ at room temperature and precipitated with ethanol. The bisulfite-modified genomic DNA was resuspended in $30 \mu \mathrm{L}$ of distilled water and immediately used or stored at $-20^{\circ} \mathrm{C}$.

\section{PCR amplification of bisulfite-modified DNA}

The sodium bisulfite modification was followed by methylation-specific PCR (MSP method). In this procedure, the treated DNA was used as a template for PCR amplification using specific primers for $R B 1$ [18] and
CDH1 [19], either methylated or modified unmethylated DNA. For PCR amplification, $4 \mu \mathrm{L}$ of treated DNA was added to a $50-\mu \mathrm{L}$ final volume of reaction mixture containing $1 \mathrm{X}$ PCR buffer, dNTPs (1.25 mM each), primers (300 ng each per reaction), $1.5 \mathrm{mM} \mathrm{MgCl}_{2}$, and 1.25 units of Taq polymerase. Both amplifications were performed in a thermocycler. The protocol for the $R B 1$ analysis was as follows: 5 minutes of initial denaturing at $96^{\circ} \mathrm{C} ; 35$ cycles at $95^{\circ} \mathrm{C}$, at $55^{\circ} \mathrm{C}$ and at $72^{\circ} \mathrm{C}$ for 1 minute at each temperature; followed by a final elongation step at $72^{\circ} \mathrm{C}$ for 7 minutes. The PCR protocol for $C D H 1$ analysis was performed as for HPV detection, as detailed previously. The primer pairs for MSP are shown in Table 1.

\section{Detection}

The amplified PCR products were detected by $10 \%$ polyacrylamide gel stained with silver nitrate. The approximate amplified fragment sizes were visualized using the 100 Base Pair Ladder molecular weight marker (Pharmacia Biotech, USA).

\section{Statistical analysis}

Statistical analysis was performed using GraphPad Software (GraphPad Software, Inc, USA). Fisher's exact test was utilized, and the differences were considered to be statistically significant when the two-tailed $\mathrm{P}$ value $<0.05$ (Confidence Interval $=95 \%$ ).

\section{Results}

\section{HPV and EBV detection}

HPV DNA was detected in $26.6 \%(4 / 15)$ of control samples, while among the case samples, this frequency was $66.0 \%(33 / 50)$, specifically $64.4 \%$ (11/17) of LSIL cases, $53.3 \%(8 / 15)$ of HSIL cases and $77.8 \%(14 / 18)$ of cervical cancer samples. A significant association was observed concerning the presence of HPV and cervical cancer $(p=0.005)$. EBV DNA was found in $53.3 \%(8 / 15)$ of control group samples, $76.4 \%(13 / 17)$ of LSIL cases, $46.7 \%(7 / 15)$ of HSIL cases and $61.1 \%(11 / 18)$ of cervical cancer samples. However, the association between EBV infection and cervical cancer was not statistically significant $(p=0.732)$. Viral co-infection was found in all groups, with the lowest frequency in the control group (13.3\%) and the highest in cancer cases (55.5\%).

Table 1 The primers pair sequences for MSP of RB1 and $C D H 1$ and the amplicon sizes

\begin{tabular}{lll}
\hline Primer Pair & Sense $\mathbf{5}^{\prime} \mathbf{- 3}$ & Antisense $\mathbf{5}^{\prime} \mathbf{- 3}$ \\
\hline RBM & GGGAGTTTCGGGACGTGAC & ACGTCGAACACGCCCCG \\
RBU & GGGAGTTTGTGGATGTGAT & ACATCAAAACACACCCCA \\
ECM & GGTGATTITTAGTAATTAGCGGTAC & CATAACTAACCGAAACGCCG \\
ECU & GGTAGGTGAATTITAGTTAATTAGTGGTA & ACCCATAACTAACCAAAAACACCA \\
\hline
\end{tabular}

$\mathrm{bp}$, base pair. 
These groups were compared, and a statistically significant association was found $(p=0.027)$. No virus infection was detected in one-third of the control samples (5/15), although in the case groups, this frequency was lower: $5.8 \%(1 / 17)$ in LSIL, $26.6 \%(4 / 15)$ in HSIL and $16.6 \%(3 / 18)$ in cancer samples. These results are summarized in Table 2.

\section{$R B 1$ and $C D H 1$ methylation}

The data concerning the promoter methylation status of $R B 1$ and $C D H 1$ are shown in Figure 1. The methylation status of both genes increased with disease progression, showing the lowest frequencies in the control $(6.7 \%$ for $R B 1$ and $13.3 \%$ for $C D H 1)$ and LSIL samples $(5.8 \%$ for $R B 1$ and $11.8 \%$ for $C D H 1$ ) and the highest in cervical cancer samples $(50.0 \%$ for $R B 1$ and $33.3 \%$ for $C D H 1)$. For $R B 1$, its methylated status was strongly associated with cancer $(p=0.009)$. However, CDH1 methylation was not shown to be associated with this cancer $(p=$ 0.241). Controls and LSIL samples did not show comethylation, while both genes were methylated in $27.8 \%$ of cancer samples (5/18). Otherwise, the unmethylated status decreased in frequency with disorder development, as $66.7 \%(10 / 15)$ of the control group and 33.3\% (6/18) of cancer cases presented an unmethylated status in both genes. That decrease was not quite statistically significant $(\mathrm{p}=0.084)$.

\section{Correlation between $R B 1 / C D H 1$ methylation status and HPV/EBV infection}

In the presence of HPV, an increased methylation status of $R B 1$ was seen with developing pathological changes (up to 50.0\%). In comparing LSIL and cancer samples, this condition was significantly associated with HPV infection $(p=0.042)$. The methylation status of $C D H 1$ increased in the presence of EBV (up to 45.5\%); however, the difference was not statistically significant $(p=0.181)$. For the $R B 1$ methylation status, only cancer samples presented methylation in the presence of HPV and EBV $(60.0 \%)$. For both genes, the global rate of methylation was higher when the virus was present: $32.4 \%$ for $R B 1$ in the presence of HPV vs. $15.3 \%$ without virus detection, and $25.0 \%$ for $C D H 1$ with HPV and EBV infection vs. $15.3 \%$ with no infection. These results are summarized in Table 3.

\section{Discussion}

The presence of abnormal DNA methylation may represent a tool for detecting potential biomarkers with important roles in cervical carcinogenesis. Furthermore, HPV/EBV infection should improve these findings because it is correlated with worse clinical presentation [20].

In a systematic review of the literature, Wentzensen et al. (2009) [20] reported that CDH1 was one of the most analyzed genes for methylation in cervical cancer. Nevertheless, a largely variable methylation frequency for both cancer and normal tissue was found among the studies. Feng et al. (2005) [21] reported the relevance of methylation in pre-cancerous lesions. Our study investigated the frequency of $R B 1$ and $C D H 1$ methylation in samples presenting all cervical carcinogenesis lesion stages and in normal tissue, in addition to reporting the correlation between this molecular event and HPV infection.

We detected HPV with a higher frequency among the case samples $(66.0 \%)$ than the control $(26.6 \%)$ in which $77.8 \%$ of the cancer group samples presented HPV. We found a very statistically significant association between HPV infection and cervical cancer $(p=0.005)$, as corroborated by the literature. In spite of that proved correlation, this infection alone is probably not sufficient to develop the disease. On the other hand, the samples in which HPV was not detected also presented cervical lesions. This molecular event was explained by Han et al. (2006) [22] and Sotlar et al. (2004) [23]. These studies show the existence of a gene deletion process in region L1 of HPV. This deletion occurs when HPV DNA integrates into the epithelial regions, and it has been described that it occurs in approximately $30 \%$ of the cases of positive cervical cancer samples. As the L1 region is the target of the primers applied in the current method

Table 2 Presence of HPV and EBV DNA in control, LSIL, HSIL and cervical cancer samples

\begin{tabular}{|c|c|c|c|c|}
\hline \multirow{2}{*}{$\begin{array}{l}\text { Control/Lesion } \\
\text { Type }\end{array}$} & \multicolumn{4}{|c|}{ HPV and EBV detection } \\
\hline & HPV, n (\%)* & $\mathrm{EBV}, \mathrm{n}(\%)^{* *}$ & HPV/EBV co-infection, $\mathrm{n}(\%)^{* * *}$ & No HPV and EBV infection, $\mathrm{n}(\%)$ \\
\hline Control $(n=15)$ & $4(26.6)$ & $8(53.3)$ & $2(13.3)$ & $5(33.3)$ \\
\hline LSIL $(n=17)$ & $11(64.7)$ & $13(76.4)$ & $8(47.1)$ & $1(5.8)$ \\
\hline HSIL $(n=15)$ & $8(53.3)$ & $7(46.7)$ & $4(26.6)$ & $4(26.6)$ \\
\hline Cancer $(n=18)$ & $14(77.8)$ & $11(61.1)$ & $10(55.5)$ & $3(16.6)$ \\
\hline Total $(n=65)$ & $37(56.9)$ & $39(60.0)$ & $24(36.9)$ & $13(20.0)$ \\
\hline
\end{tabular}

${ }^{*} p=0.005$ (Control versus Cancer).

$*^{* *} p=0.732$ (Control versus Cancer).

$* * * p=0.027$ (Control versus Cancer).

LSIL, low-grade squamous intraepithelial lesions; HSIL, high-grade squamous intraepithelial lesions. 


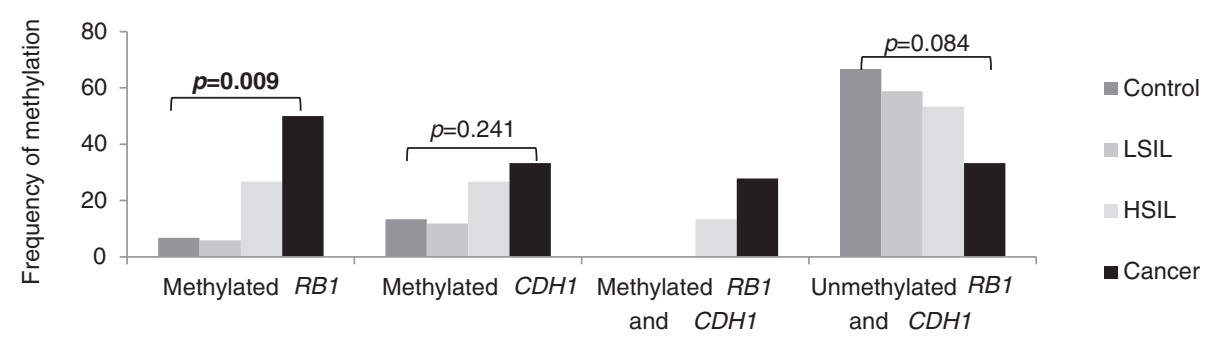

Figure $1 R B 1$ and $C D H 1$ promoter methylation status. LSIL, low-grade squamous intraepithelial lesions; HSIL, high-grade squamous intraepithelial lesions.

for HPV detection, the absence of HPV detection in cancer cases could be explained by its deletion. Additionally, studies [24-28] about the Brazilian prevalence of HPV show that it is lower than in data from Walboomers et al. (1999) [29], which may be explained by the occurrence of the integration events affecting L1 sequences

EBV infection was found in a series of cases and control groups in which the rate of detection frequency was not considered statistically significant $(p=0.732)$. This finding indicates that EBV cannot be responsible for cervical cancer progression alone. Nevertheless, cancer was revealed to be associated with HPV and EBV coinfection $(\mathrm{p}=0.027)$, showing its possible role as a cofactor in cervical cancer progression. Some preliminary studies found similar results (Nichols et al., 2011 [30]; Ekalaksananan et. al, 2011 [31]), indicating an association between coinfection with these viruses and cervical cancer progression. In a recent study, Khenchouche et al. (2013) [32] also highlighted the importance of this co-infection for cervical cancer progression, adding that it could be considered as a bad prognosis for this type of cancer.

In our study, the methylation status of both genes, RB1 and CDH1, increased with the severity of the cervical lesion, suggesting that the frequency of methylation was higher in cancers $(50.0 \%$ for RB1 and $33.3 \%$ for $\mathrm{CDH} 1)$ than in the other lesions and controls $(6.7 \%$ for $\mathrm{RB} 1$ and $13.3 \%$ for $\mathrm{CDH} 1$ in controls). These data for $\mathrm{CDH} 1$ are consistent with findings in the literature (Chen et al., 2003 [33]; Dong et al., 2001 [34]; Narayan et al., 2003 [35]; Attaleb et al., 2009 [36]), which showed that $\mathrm{CDH} 1$ was methylated in less than $50 \%$ of cervical cancer samples, indicating that partial promoter methylation of the $\mathrm{CDH} 1$ can down-regulate the gene expression. Despite this, our data revealed that the association between $\mathrm{CDH} 1$ methylation and cancer was not significant $(p=0.241)$. Few studies have addressed RB1 methylation and its correlation with cervical carcinogenesis, and this issue needs to be further investigated. However, our results showed an expressive correlation between RB1 methylation and cancer samples ( $p=0.009)$. It might be potentially used as a valuable marker for tumor diagnosis.

Only HSIL and the cancer group presented methylation in both genes simultaneously $(13.3 \%$ and $27.8 \%$, respectively), and these groups had the lowest frequencies for the unmethylated status in both genes (53.3\% and 33.3\%, respectively). Our findings also agree with those of Narayan et al. (2003) [35], who analyzed the methylation status of a group of genes in cervical carcinogenesis, including $R B 1$ and $C D H 1$, and concluded that global promoter methylation was higher in more advanced stages of the disease. However, they did not find promoter methylation in the $R B 1$ gene. Our results indicate that these differences may be involved in the disease progression.

Table 3 Comparison between RB1/CDH1 methylation and HPV/EBV infection, reporting the percentages of methylated cases among HPV/EBV positive cases

\begin{tabular}{|c|c|c|c|c|c|c|c|c|}
\hline \multirow{3}{*}{$\begin{array}{l}\text { Control/Lesion } \\
\text { Type }\end{array}$} & \multicolumn{8}{|c|}{ Methylation Status } \\
\hline & \multicolumn{4}{|l|}{$R B 1$} & \multicolumn{4}{|l|}{$\mathrm{CDH} 1$} \\
\hline & $\begin{array}{l}\mathrm{HPV}+ \\
\mathrm{n}(\%)^{*}\end{array}$ & $\begin{array}{l}\text { EBV+, } \\
\text { n (\%) }\end{array}$ & $\begin{array}{l}\text { HPV and } \\
\text { EBV+, n (\%) }\end{array}$ & $\begin{array}{l}\text { HPV and EBV-, } \\
\text { n (\%) }\end{array}$ & $\begin{array}{l}\mathrm{HPV+} \\
\mathrm{n}(\%)\end{array}$ & $\begin{array}{l}\text { EBV+, } \\
\text { n }(\%)^{* *}\end{array}$ & $\begin{array}{l}\text { HPV and EBV+, } \\
\text { n (\%) }\end{array}$ & $\begin{array}{l}\text { HPV and EBV-, } \\
\text { n (\%) }\end{array}$ \\
\hline Control $(n=15)$ & $0(0.0)$ & $0(0.0)$ & $0(0.0)$ & $1(20.0)$ & $1(25.0)$ & $0(0.0)$ & $0(0.0)$ & $1(20.0)$ \\
\hline LSIL $(n=17)$ & $1(9.1)$ & $0(0.0)$ & $0(0.0)$ & $0(0.0)$ & $0(0.0)$ & $2(15.3)$ & $0(0.0)$ & $0(0.0)$ \\
\hline HSIL $(n=15)$ & $4(50.0)$ & $0(0.0)$ & $0(0.0)$ & $0(0.0)$ & $4(50.0)$ & $2(28.6)$ & $2(50.0)$ & $0(0.0)$ \\
\hline Cancer $(n=18)$ & $7(50.0)$ & 7 (63.6) & $6(60.0)$ & $1(33.3)$ & $4(28.6)$ & $5(45.5)$ & $4(40.0)$ & $1(33.3)$ \\
\hline Total $(n=65)$ & $12(32.4)$ & $7(17.9)$ & $6(25.0)$ & $2(15.3)$ & $9(24.3)$ & $9(23.1)$ & $6(25.0)$ & $2(15.3)$ \\
\hline
\end{tabular}


We also analyzed the potential association between RB1/CDH1 methylation status and HPV/EBV infection. Our findings showed an important increase in the methylation status of both genes, $R B 1$ and $C D H 1$, with a pathological change seen with HPV/EBV infection. It is important to note that the methylated status of $R B 1$ was considered to be associated with HPV infection $(p=0.042)$, revealing an important role for HPV in cervical cancer epigenetics.

The elucidation of the molecular relationships between viral and host proteins and their epigenetic modifications could improve the process of cervical cancer screening. Indeed, the detection of possible biomarkers and cofactors for the possibility of cervical cancer could allow for molecular differentiation between initial and precursor lesions.

\section{Conclusions}

In conclusion, our results showed that the methylation status of both genes increased with disease progression, revealing a significant correlation between $R B 1$ methylation and cervical cancer. With EBV, the methylation of $R B 1$ was a tumor-associated event, where only the cancer group presented $R B 1$ methylation in the presence of this virus. HPV infection and cancer progression were significantly associated. The global frequency of methylation was higher when HPV was present, showing its important role in this epigenetic mechanism in cervical carcinogenesis. Nevertheless, EBV seems to have a cofactor role in this process, which needs to be further investigated.

\section{Competing interests}

The authors declare that they have no competing interests.

\section{Authors' contribution}

TMC and MGC are the molecular biologists who wrote the paper and carried out the molecular assays. YF, FS and GA are the gynecologists of the group, who selected patients and collected samples. RL, NC and AR are the pathologists and were responsible for diagnostic. All authors read and approved the final manuscript.

\section{Authors' information}

TMC, MS, researcher at Department of Pathology of Medical School of Federal University of Rio de Janeiro, Brazil.

NHSC, MD, PhD, pathologist at Pathological Anatomy Service and Pathology Department, Clementino Fraga Filho University Hospital, Federal University of Rio de Janeiro - UFRJ, Brazil.

YF, MD, PhD, gynecologist at Gynecology Institute, Federal University of Rio de Janeiro - UFRJ, Brazil.

FAS, MD, PhD, gynecologist at Gynecology Institute, Federal University of Rio de Janeiro - UFRJ, Brazil.

RJL, MD, MS, pathologist at Gynecology Institute, Federal University of Rio de Janeiro - UFRJ, Brazil.

ADFR, MD, MS, pathologist at Gynecology Institute, Federal University of Rio de Janeiro - UFRJ, Brazil.

GLAF, MD, PhD, gynecologist and director of Gynecology Institute, Federal University of Rio de Janeiro - UFRJ, Brazil.

MGCC, MD, PhD, researcher at Department of Pathology of Medical School of Federal University of Rio de Janeiro, Brazil.

\section{Acknowledgments}

The authors thank Marcelo Soares da Mota e Silva for excellent technical assistance. This work was supported by CNPq and Fundação do Câncer.

\section{Author details}

${ }^{1}$ Laboratory of Molecular Pathology, Pathological Anatomy Service and Pathology Department, Clementino Fraga Filho University Hospital, Federal University of Rio de Janeiro - UFRJ, Rio de Janeiro, Brazil. ${ }^{2}$ Laboratory of Neuropathology, Pathological Anatomy Service and Pathology Department, Clementino Fraga Filho University Hospital, Federal University of Rio de Janeiro - UFRJ, Rio de Janeiro, Brazil. ${ }^{3}$ Gynecology Institute, Federal University of Rio de Janeiro - UFRJ, Rio de Janeiro, Brazil. ${ }^{4}$ Serviço de Anatomia Patológica, Subsolo - sala 09 (Citopatologia), Hospital Universitário Clementino Fraga Filho, UFRJ, Ilha do Fundão, Rio de Janeiro, RJ CEP 21941-913, Brazil.

Received: 11 November 2014 Accepted: 22 April 2015

Published online: 02 June 2015

\section{References}

1. Ministério da Saúde, Instituto Nacional de Câncer. In: da Silva JAG, editor. Estimativa 2014: Incidência de Câncer no Brasil. Rio de Janeiro: INCA; 2014. p. 124

2. Ministério da Saúde, Instituto Nacional de Câncer. In: da Silva JAG, editor. Estimativa 2012: Incidência de Câncer no Brasil. Rio de Janeiro: INCA; 2011. p. 118.

3. Zur Hausen H. Papillomavirus infections - a major cause of human cancers. Biochim Biophys Acta. 1996;1288:F55-78.

4. Badal V, Chuang LSH, Tan EHH, Badal S, Villa LL, Wheeler CM, et al. CpG methylation of human papillomavirus type 16 DNA in cervical cancer cell lines and in clinical genomic hypomethylation correlates with carcinogenic progression. J Virol. 2003;77(11):6227-34.

5. Burd EM. Human papillomavirus and cervical cancer. Clin Microbiol Rev. 2003;16(1):1-17.

6. Zur Hausen H. Papillomaviruses and cancer: from basic studies to clinical application. Nature Rev Cancer. 2002;2:342-50.

7. Lu Q, Ma D, Zhao S. DNA methylation changes in cervical cancers. Methods Bio Mol. 2012;863:155-76.

8. Jiang M, Milner J. Selective silencing of viral gene expression in HPV-positive human cervical carcinoma cells treated with siRNA, a primer of RNA interference. Oncogen. 2002;21:6041-8.

9. Dueñas-González A, Lizano M, Candelaria M, Cetina L, Arce C, Cervera E. Epigenetics of cervical cancer: An overview and therapeutic perspectives. Mol Cancer. 2005;4:38.

10. Laurson J, Khan S, Chung R, Cross K, Raj K. Epigenetic repression of E-cadherin by human papillomavirus 16 E7 protein. Carcinogenesis. 2010;31(5):918-26.

11. Al-Daraji WI, Smith JHF. Infection and cervical neoplasia: facts and fiction. Int J Clin Exp Pathol. 2009;2:48-64.

12. Etoh T, Kanai Y, Ushijima S, Nakagawa T, Nakanishi Y, Sasako M, et al. Increased DNA methyltransferase 1 (DNMT1) protein expression correlates significantly with poorer tumor differentiation and frequent DNA hypermethylation of multiple CpG islands in gastric cancers. Am J Pathol. 2004;164:689-99.

13. Lattario F, Furtado YL, Fonseca R, Silveira FA, Do Val IC, Almeida G, et al. Analysis of human papillomavirus and Epstein-Barr virus infection and aberrant death-associated protein kinase methylation in high-grade squamous intraepithelial lesions. Int J Gynecol Cancer. 2008;18:785-9.

14. Pestaner C, Bibbo M, Bobroski L, Seshamma T, Bagasra O. Potencial of the in situ Polymerase Chain Reaction in diagnostic cytology. Acta Cytological. 1994;38:676-80.

15. Manos MM, Ting Y, Wright DK, Lewis AJ, Broker TR, Wolinsky SM. Use of polymerase chain reaction amplification for the detection of genital human papillomavirus. Cancer Cells. 1989;7:209-14.

16. Saito I, Servenius B, Compton T, Fox Rl. Detection of Epstein-Barr virus DNA by polymerase chain reaction in blood and tissue biopsies from patients with Sjogren's syndrome. J Exp Med. 1989;169:2191-8.

17. Rosas SLB, Caballero OL, Dong SM, Carvalho MGC, Sidransky D, Jen J. Methylation status in the promoter region of human PGP9.5 gene in cancer and normal tissue. Cancer Lett. 2001;170:235-46. 
18. Simpson DJ, Hibberts NA, McNicol AM, Clayton RN, Farrell WE. Loss of pRb Expression in Pituitary Adenomas Is Associated with Methylation of the RB1 CpG Island. Cancer Res. 2000;60:1211-6.

19. Graff JR, Herman JG, Myo ha"nen S, Baylin SB, Vertino PM. Mapping Patterns of CpG Island Methylation in Normal and Neoplastic Cells Implicates Both Upstream and Downstream Regions in de Novo Methylation. J Biol Chem. 1997;272:22322-9.

20. Wentzensen N, Sherman ME, Schiffman M, Wang SS. Utility of methylation markers in cervical cancer early detection: Appraisal of the state-of-the-science. Gynecol Oncol. 2009;112:293-9.

21. Feng Q, Balasubramanian A, Hawes SE, Toure P, Sow PS, Dem A, et al. Detection of hypermethylated genes in women with and without cervical neoplasia. J Natl Cancer Inst. 2005;97:273-82.

22. Han J, Swan DC, Smith SJ, Lum SH, Sefers SE, Unger ER, et al. Simultaneous amplification and identification of 25 human papillomavirus types with templex technology. J Clin Microbiol. 2006;44(11):4157-62.

23. Sotlar K, Diemer D, Dethleffs A, Hack Y, Stubner A, Vollmer N, et al Detection and typing of human papillomavirus by E6 nested multiplex PCR. J Clin Microbiol. 2004;42(7):3176-84.

24. Ayres ARG, Azevedo-Silva G. Cervical HPV infection in Brazil: systematic review. Rev Saúde Pública. 2010;44(5):963-74.

25. Rabelo-Santos SH, Zeferino L, Villa LL, Sobrinho JP, Amaral RG, Magalhães AV. Human Papillomavirus Prevalence among Women with Cervical Intraepithelial Neoplasia III and Invasive Cervical Cancer from Goiânia, Brazil. Mem Inst Oswaldo Cruz. 2003;98(2):181-4.

26. Baay MFD, Quint WGV, Koudstall J, Hollema H, Duk JM, Burger MPM, et al. Comprehensive study of several general and type-specific primer pair for detection of human papillomavirus DNA by PCR in paraffin-mbedded cervical carcinomas. J Clin Microbiol. 1996;34:745-7.

27. Unger ER, Vernon SD, Lee DR, Miller DL, Reeves WC. Detection of human papillomavirus in archival tissues: comparison of in situ hybridization and polymerase chain reaction. J Histochem Cytochem. 1998;46:535-40.

28. Noronha V, Mello W, Villa LL, Macedo R, Bisi F, Mota R, et al. Human papillomavirus associated with uterine cervix lesions. Rev Soc Bras Med Trop. 1999;32:235-40.

29. Walboomers JM, Jacobs MV, Manos MM, Bosch FX, Kummer JA, Shah KV, et al. Human papillomavirus is a necessary cause of invasive cervical cancer worldwide. J Pathol. 1999;189:12-9.

30. Nichols W, Sutton K, Nelson N, Clark A, Oddo H, Love N, Hagensee M. 27th International Papillomavirus Conference and Clinical Workshop. Berlin, Germany; 2011. (Abstract), Epstein-Barr virus as a Potential Biomarker for Cervical Dysplasia; pp.14-15. (Abstract book 2, page 59)

31. Ekalaksananan T, Aromseree S, Pientong C, Sunthamala N, Swangphon P, Chaiwongkot A, Kongyingyoes B, Patarapadungkit N, Chumworathayee B. 27th International Papillomavirus Conference and Clinical Workshop. Berlin, Germany; 2011. (Abstract), Co-infection of Epstein-Barr Virus (EBV) with High Risk Human Papillomavirus (HR-HPV) is a Significant Risk of Cervical Cancer; pp. 14-33. (Abstract book 2, page68)

32. Khenchouche A, Sadouki N, Boudriche A, Houali K, Graba A, Ooka T, et al. Human papillomavirus and Epstein-Barr virus co-infection in cervical carcinoma in Algerian women. Virol J. 2013;10:340.

33. Chen CL, Liu SS, Ipb SM, Wongb LC, Ng TY, Nganb HYS. E-cadherin expression is silenced by DNA methylation in cervical cancer cell lines and tumours. Eur J Cancer. 2003;39:517-23.

34. Dong SM, Kim HS, Rha SH, Sidransky D. Promoter hypermethylation of multiple genes in carcinoma of the uterine cervix. Clin Cancer Res. 2001;7:1982-6.

35. Narayan G, Arias-Pulido H, Koul S, Vargas H, Zhang FF, Villella J, et al. Frequent promoter methylation of CDH1, DAPK, RARB, and HIC1 genes in carcinoma of cervix uteri: its relationship to clinical outcome. Mol Cancer. 2003;2:24-35.

36. Attaleb M, El hamadani W, Khyatti M, Benbacer L, Benchekroun N, Benider A, et al. Status of p16INK4a and E-Cadherin genes promoter methylation in Moroccan patients with cervical carcinoma. Oncol Res. 2009;18:185-92.

\section{Submit your next manuscript to BioMed Central and take full advantage of:}

- Convenient online submission

- Thorough peer review

- No space constraints or color figure charges

- Immediate publication on acceptance

- Inclusion in PubMed, CAS, Scopus and Google Scholar

- Research which is freely available for redistribution

Submit your manuscript at www.biomedcentral.com/submit 